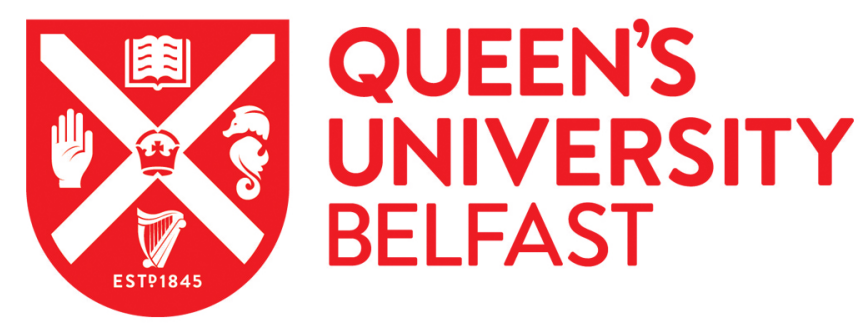

\title{
Differing Knowledges: Comparing the contribution of drama students and service users in role plays preparing social work students for practice
}

Duffy, J., Montgomery, L., Murphy, P., Davidson, G., \& Bunting, L. (2021). Differing Knowledges: Comparing the contribution of drama students and service users in role plays preparing social work students for practice. Social Work Education. https://doi.org/10.1080/02615479.2020.1717461

Published in:

Social Work Education

Document Version:

Peer reviewed version

Queen's University Belfast - Research Portal:

Link to publication record in Queen's University Belfast Research Portal

\footnotetext{
Publisher rights

(c) 2020 Informa UK Limited, trading as Taylor \& Francis Group. This work is made available online in accordance with the publisher's policies. Please refer to any applicable terms of use of the publisher.
}

\section{General rights}

Copyright for the publications made accessible via the Queen's University Belfast Research Portal is retained by the author(s) and / or other copyright owners and it is a condition of accessing these publications that users recognise and abide by the legal requirements associated with these rights.

\section{Take down policy}

The Research Portal is Queen's institutional repository that provides access to Queen's research output. Every effort has been made to ensure that content in the Research Portal does not infringe any person's rights, or applicable UK laws. If you discover content in the Research Portal that you believe breaches copyright or violates any law, please contact openaccess@qub.ac.uk. 
Differing Knowledges: Comparing the contribution of drama students and service users in role plays preparing social work students for practice.

\author{
Joe Duffy, PhD. \\ Senior Lecturer in Social Work \\ School of Social Sciences, Education and Social Work \\ 6 College Park \\ Queen's University \\ Belfast BT7 1LP \\ Northern Ireland \\ Tel +442890975909 \\ e-mail: joe.duffy@qub.ac.uk \\ Lorna Montgomery, PhD. \\ Lecturer in Social Work \\ School of Social Sciences, Education and Social Work \\ 6 College Park \\ Queen's University \\ Belfast BT7 1LP \\ Northern Ireland \\ e-mail:1.montgomery@qub.ac.uk
}

Paul Murphy, PhD.

Lecturer in Drama Studies

School of Arts, English and Languages

21 University Square 


\section{Queen's University Belfast, BT7 1PA \\ e-mail: p.murphy@qub.ac.uk}

Gavin Davidson, PhD.

Professor in Social Care

School of Social Sciences, Education and Social Work

6 College Park

Queen's University

Belfast BT7 1LP

Northern Ireland

e-mail: g.davidson@qub.ac.uk

\section{Lisa Bunting, PhD.}

Lecturer in Social Work

School of Social Sciences, Education and Social Work

6 College Park

Queen's University

Belfast BT7 1LP

Northern Ireland

e-mail: 1.bunting@qub.ac.uk

3 January 2020 


\begin{abstract}
Much has been written about service user involvement in social work education with the literature recognising the value of this particular type of experiential knowledge in helping students understand key competences and concepts. There is also extensive literature highlighting the role of simulation in assisting social work students develop key insights in regard to skills and knowledge through role plays. Using a Cross-Over design, this paper compares the contribution of drama students with service users in the preparation of social work students for field practice in Northern Ireland. Our findings suggest there is an important role for both drama students and service users working collaboratively to help social work students develop in key areas of social work competence and have implications for social work education in an international context.
\end{abstract}

Key Words: Service user involvement, simulation, drama students, social work education 


\section{Introduction}

A now established element of social work education in the United Kingdom (UK), the mandatory involvement of service users and carers features in all aspects of social work education (McLaughlin et al, 2018) with service users and carers occupying a central space in key aspects of social work teaching and curriculum development. Involving this service user standpoint (McLaughlin, 2009) in social work education mirrors an established policy trajectory, where hearing the user voice is now a commonplace expectation in in the U.K. context. Consequently, there is increasing recognition that knowledge, based on lived experience, has a key part to play in social work education, policy and research alongside more traditional knowledge forms (Beresford, 2013).

This pedagogic research examines the comparative contribution of simulation (engaging drama students) and experience-based knowledge (engaging service users) to the skills development of social work students in a university in Northern Ireland. As a result of increasing collaboration with colleagues in Drama, we were discovering areas of the social work curriculum where drama students were helping us with simulating some of the more challenging practice aspects of social work, for example child protection. Involving service users and carers in our social work programme was already well embedded and respected but we felt that the time was right to look in closer detail at the type of learning our social work students were gleaning from the involvement of both service users and drama students in the development of their practice skills. The research findings reported in this paper, therefore, focus on the contributions of both drama students and service users to social work students' practice across the following important areas: Nervousness, confidence in use of skills, ability to show empathy, testing of skills, approximation of real life and overall rating of the learning experience. These outcomes were selected based on Carpenter's (2011) work on evaluating social work education, and on previous related research on preparing students for practice 
(Duffy et al, 2012; Duffy, 2015). In the interests of brevity, the term service user is used to describe social work service recipients and carers whilst recognising that the language of 'involvement' is both political and contested (McLaughlin, 2009). Firstly, it is important to examine the key messages from literature in regard to both service user and simulator involvement in social work education.

\section{Literature Overview}

Social work education in the U.K. was significantly reformed in 2002 (Department of Health, 2002) with Northern Ireland following suit with the introduction of a generic, competence based Social Work Degree in 2004 (DHSSPS, 2003). One of the central tenets of these reforms was the position that service users would have in key aspects of both teaching and contributing to the strategic oversight of social work courses across all regions of the U.K. (Levin, 2004; Duffy, 2006). As noted, the increasing recognition of service user knowledge was already important in policy domains, and in the education and training of social work professionals (Beresford, 2000; 2013). It is, thus, now commonplace to see service user involvement in social work teaching, small group tutorials, course management and assessment (Duffy et al, 2012; Robinson and Webber, 2013; McLaughlin et al, 2018).

The underpinning philosophy in this approach to pedagogy is that there is something distinctive in what lived, experience-based knowledge brings to learning for social work students. The literature refers to examples of this in regard to improved understanding of empathy, communications skills, social work values, international and global aspects and understanding trauma and political conflict (Robinson and Webber, 2013; McLaughlin, 2009; Duffy, 2012; Duffy et al, 2012; McLaughlin et al, 2018). However, the language of involvement is itself political with McLaughlin (2009) suggesting that the term 'service user' is restrictive with its 
focus solely on the relationship a person has with a service. Consequently, there is the potential for 'service user' to be othered and to be regarded as outside of a particular norm. Beresford, instead, argues that influence, choice, engagement and control are attributes that need highlighted over perceptions of passivity (2005, p.471). Knowledge that derives from lived experience may, however, be regarded as not having the same intellectual gravitas as that which is viewed as more objective, expert, propositional and less reliant on 'the personal' (Eraut 1996; Fook 2002). Concerns about "ordinary people taking on powerful roles" links directly to the fundamentals of this epistemic debate (Rimmer 1997, p. 33) and these critical questions appear in other aspects of the literature (Popay and Williams 1996; Prior 2003; McLaughlin 2009; El Enany et al, 2013). Trevithick, however, argues that service user knowledge has an important and recognised position within social work's generic knowledge base and situates this within a factual domain in social work (2008). Service users may also doubt the capacity for their lived experience to contribute to social work students' understanding and insights, therefore reflecting a crisis in their own confidence. "It makes you realise how much you have to share" was an observation by a service user previously reflecting on the experience of sharing personal testimony with social work students (Duffy et al, 2012). Indeed, these sentiments arguably chime with Cotterell and Morris' observations that service users on the margins of society view their lived experiences as being of less value (2012). The seminal 'Pedagogy of the Oppressed' by Paulo Freire (1972) may illuminate the social justice aspects of service users being involved in this type of reflexivity where he states that: "only a critical consciousness of the knowledge in one's possession can in turn lead to action and transformation" (cited in Cotterell and Morris, 2012, p. 60). In their previously mentioned paper above, Duffy et al (2012) observed this type of reflexivity occurring with a practice teacher remarking "I've been turned around" following closely working with a service user in teaching. It would, therefore, seem that this type of 
pedagogy of lived experience has the capacity to generate moments for both reflection and reflexion for all of the participants involved.

Turning to the deployment of drama in terms of role-play in scenario-based learning in social work, this could be described as a form of 'applied' drama or theatre (Taylor 2003; Thompson, 2003; Nicholson, 2005, 2014). Ackroyd (2000) observes that applied theatre is an umbrella term to cover various kinds of educational and community-oriented theatre such as theatre in education, theatre in hospitals, drama therapy and other activities, each of which has their own particular theories and practices. In the context of this pedagogic research, the word drama seems most apposite given that the focus is on the activity rather than the specific location. The use of drama within social work training is, however, more complicated insofar as drama has not been 'applied' in the strict sense but has developed organically in order to simulate the reallife situations in which a social worker would interview or otherwise engage with a service user.

The approach in this study contributes to knowledge and understanding insofar as the drama students are not only performing the role of service users in various scenarios but are also offering detailed analysis of the social work students' performance. A professional actor would only be expected to perform the role, whereas a drama student in this study is performing the role and providing bespoke feedback because they have been trained do so in specific drama training seminars. During the course of their three-year degree programme, drama students are taught to analyse performance from a wide variety of perspectives including theatre criticism of the kind advocated by Fisher (2015). The students are also taught to engage in performance, using techniques from the Stanislavski 'System' of actor training (Stanislavski 2016; Benedetti 2016) amongst other approaches to acting. In the interdisciplinary module on which this study focuses, the drama students prepared for the collaboration with social work by working in pairs to alternate performing as the social worker and the service user to appreciate the nuances of 
both perspectives. By way of further preparation, the drama students also engaged with relevant research literature in social work education, including Reupert's work on the social worker's use of self (2007), students' use of self (2009) and the involvement of service users in social work education (Hernandez et al, 2010; Duffy et al, 2012). This level of preparation enabled the drama students to understand the various roles involved in this specific preparation for practice learning sequence. The drama students, with the combined knowledge and experience of drama with that of social work education, were facilitated in providing tailored feedback on the performance of the social work students after the role play. The approach, therefore, indicates the value of combining acting training in parallel with performance analysis training for drama students performing the role of service users.

\section{Educational Context}

The setting for this study was the Preparation for Practice Learning module for social work students at a university in Northern Ireland. The main focus of this module is to prepare and assess social work students for their first field practice placement. In order to progress to placement, the students must successfully complete three assessed role-play interviews which are based on real case scenarios.

The module is taught jointly to three cohorts of students: Undergraduate Route (UGR) students who are studying social work over three years; Part Time Route (PTR) students who are studying the same course but over five years; and Relevant Graduate Route (RGR) students studying a fast track course over two years as they already have a background qualification cognate to social work. 


\section{Method}

The research was designed to compare the learning experience of social work students when they were performing role plays with drama students with when they were working with service users. Until this initiative, the student role plays were assessed by the practice teacher and academic tutor working with the participating service users giving feedback on the case scenarios they had developed on a real aspect of their lived experience. For this research, however, we extended the team to include the drama students who would also perform preagreed case scenarios developed by one of the authors. The drama students were final year degree students with substantial knowledge of the theory and experience in the practice of drama. On this module, assessed role plays occur during Weeks 4 and 7 of the semester facilitating students to practice skills before their assessment in Week 4, to further develop skills before a second assessment point in Week 7 and to continue to refine skills across the remainder of the 12 week module. As there is a natural development process across the module, it was important to ensure that students' experiences were investigated without the effects of timing and/or order. Thus, the cohort of students was split in two, one group worked with drama students in Week 4 and then service users in Week 7 (The Drama/Service User group). The other group worked with service users in Week 4 and drama students in Week 7 (The Service User/Drama group)._There were thus four main contributing perspectives in this research process: The social work students; the drama students; the service users; and the academic/field instructor teaching dyads. Data collection for the study involved a range of methods for each of these groups.

For the social work students $(n=115)$, an online survey was designed using Survey Monkey. The survey questions focused on the students' learning experiences and asked them to compare their experiences with drama students and service user educators in their role plays. This 
included questions, using a seven-point Likert Scale from Very Poor to Excellent on the following key areas: nervousness; confidence; empathy; how well their skills were tested; how close it felt to real life; and how it was as a learning experience. It also asked students: to report the strengths and limitations of working with both groups; what they preferred; and how well they felt working with both groups prepared them for practice.

For the other three groups (drama students, $n=10$, academic tutors $n=18$ and service user educators, $n=8$ ) a focus group approach was used to elicit their perspectives and reflections on the experience for the social work students. As with the survey, the focus group questions addressed the domains of nervousness, confidence, empathy; testing of skills, approximation to real life and overall quality of the learning experience. Ethical approval was obtained from the appropriate department in the university. Informed consent was a key component of each method for data collection, on-line survey and focus group, and this was made clear in the participant information documentation and at the beginning of the survey where relevant background information on the research project was explained in detail for all respondents. The service users involved in this pedagogic research project were also very experienced and accustomed to providing feedback having previously worked with the lead author on similar projects (Duffy et al, 2012) as well as taking part in a previous training course designed to support service user involvement in the social work Degree. They were, therefore, very attuned to the need to provide constructive, helpful and balanced feedback to the students in an assessment context. The advice provided to the service users by the team in regard to feedback was also informed by critical and key messages from the literature in regard to this (for example, Shennan, 1998; Thomas, 2002; Edwards, 2003; Skilton, 2011; Hitchin, 2016; Driessens, et al, 2016). An ethic of care approach was also an important compass for our team in ensuring that service users were fully supported in this entire research process (Hugman, 
2005; Ward and Gahagan, 2012). Service users were also remunerated for their involvement through the university's annual funding which supports a range of involvement activities in the Degree. Drama students, though not paid for their involvement, gained important experience and feedback from the assessment dyads which would assist in their skills development at an important stage of their studies.

\section{Findings}

As presented in Table 1, a total of 89 students completed the evaluation. Eighty-seven per cent were female and the average age was 29 years, with over half being under the age of 30 years. Fifty-six per cent were studying on the UGR course. In terms of the skills role plays, 55\% completed a role play with a drama student in Week 4 followed by a service user in Week 7 (The Drama/Service User Group) and 45\% completed a role play with a service user in Week 4 followed by a drama student in Week 7 (The Service User/Drama Group).

Table 1 - Sample Characteristics

\begin{tabular}{|lll|}
\hline Variable & No & \% \\
Gender & & \\
Male & 12 & 13.5 \\
Female & 77 & 86.5 \\
Age & & \\
Under 30 years & 56 & 62.9 \\
30 years+ & 33 & 37.1 \\
& & \\
Degree Route & 50 & 56.2 \\
UGR & 34 & 38.2 \\
RGR & 5 & 5.6 \\
PTR & & \\
Group & & \\
Drama/Service user & 40 & 44.9 \\
Service User/Drama & 49 & 55.1 \\
\hline
\end{tabular}




\section{Evaluating Service User and Drama Student Role Plays at Week 4 and 7}

Across the sample, students reported reduced nervousness, increased confidence in the use of their skills, ability to show empathy, greater approximation of the role play to real life practice and higher overall rating of the learning experience between Week 4 and Week 7 (Table 2, median scores are presented due to the non-normal distribution of the data).

Non-parametric Mann U Whitney Independent Samples tests showed that, at Week 4 and Week 7 there were no differences between the groups in relation to confidence (Table 2). However, at both time points, those who had a service user role play were more likely to give a higher overall rating of the learning experience and to report increased ability to demonstrate empathy, increased testing of their skills and greater approximation of reality, than those who had a drama student role play. Additionally, those who had a drama student role play at Week 7 were likely to report less nervousness than those who had a service user role play. Further Mann U Whitney tests indicate that this was influenced by age with students under 30yrs who had a service user role play at Week 7 reporting significantly higher levels of nervousness compared to those aged $30+(\mathrm{z}=2.421, \mathrm{p}=.015)$. Gender was not included in analysis as all the male students were in the 'service user at Week 4/drama student at Week 7 group'.

Table 2 - Differences between groups at Week 4 and Week 7

\begin{tabular}{|l|l|l|l|l|l|l|}
\hline \multicolumn{7}{|c|}{ Week 4 } \\
\hline & Drama (n=40) & \multicolumn{2}{|l|}{ Service User (n=49) } & U & p \\
\hline & Mdn & Range & Mdn & Range & & \\
\hline Nervousness & 5.00 & 6 & 6.00 & 5 & 972.500 & 0.949 \\
\hline $\begin{array}{l}\text { Confidence in use } \\
\text { of skills }\end{array}$ & 4.00 & 5 & 4.00 & 4 & 892.500 & 0.455 \\
\hline $\begin{array}{l}\text { Ability to show } \\
\text { empathy }\end{array}$ & 4.00 & 5 & 5.00 & 5 & 675.500 & 0.010 \\
\hline Testing of skills & 4.50 & 5 & 6.00 & 6 & 644.000 & 0.004 \\
\hline $\begin{array}{l}\text { Approximation of } \\
\text { real life }\end{array}$ & 2.00 & 5 & 4.00 & 6 & 565.000 & 0.001 \\
\hline $\begin{array}{l}\text { Overall rating of } \\
\text { the learning } \\
\text { experience }\end{array}$ & 4.00 & 6 & 6.00 & 6 & 596.000 & 0.001 \\
\hline
\end{tabular}




\begin{tabular}{|c|c|c|c|c|c|c|}
\hline \multicolumn{7}{|c|}{ Week 7} \\
\hline & \multicolumn{2}{|c|}{ Service User $(n=40)$} & \multicolumn{2}{|c|}{ Drama $(n=49)$} & \multirow[t]{2}{*}{$\mathbf{U}$} & \multirow[t]{2}{*}{$\mathbf{p}$} \\
\hline & $M d n$ & Range & $M d n$ & Range & & \\
\hline Nervousness & 6.00 & 4 & 4.00 & 5 & 656.500 & 0.007 \\
\hline $\begin{array}{l}\text { Confidence in use } \\
\text { of skills }\end{array}$ & 5.00 & 4 & 5.00 & 6 & 908.500 & 0.524 \\
\hline $\begin{array}{l}\text { Ability to show } \\
\text { empathy }\end{array}$ & 6.00 & 3 & 6.00 & 6 & 718.500 & 0.021 \\
\hline Testing of skills & 6.00 & 4 & 6.00 & 6 & 630.500 & 0.003 \\
\hline $\begin{array}{l}\text { Approximation of } \\
\text { real life }\end{array}$ & 6.00 & 6 & 5.00 & 6 & 521.500 & 0.000 \\
\hline $\begin{array}{l}\text { Overall rating of } \\
\text { the learning } \\
\text { experience }\end{array}$ & 6.00 & 6 & 6.00 & 6 & 676.500 & 0.009 \\
\hline
\end{tabular}

\section{Evaluating Drama/Service User and Service User/Drama Groups over Time}

Wilcoxon Signed-Ranks tests indicated that those in the Drama/Service User Group reported no significant difference in nervousness over time $(\mathrm{z}=.743, \mathrm{p}=0.457)$. However, they did report significantly higher levels of confidence $(\mathrm{z}=3.026, \mathrm{p}=0.002)$, greater ability to show empathy $(\mathrm{z}=4.703, \mathrm{p}<0.001)$, increased testing of skills $(\mathrm{z}=4.591, \mathrm{p}<0.001)$, greater approximation to real life $(\mathrm{z}=4.923 \mathrm{c}, \mathrm{p}<0.001)$ and higher overall ratings of the learning experience $(\mathrm{z}=4.496$, $\mathrm{p}<0.001)$ at Week 7 . Tests for the effects of age showed that students under $30 \mathrm{yrs}$ and those aged 30+yrs both showed the same pattern across domains.

Those in the Service User/Drama Group reported no significant differences in relation to testing of skills $(\mathrm{z}=.451, \mathrm{p}=0.652)$, greater approximation to real life $(\mathrm{z}=-.774, \mathrm{p}=.439)$ and overall ratings of the learning experience $(\mathrm{z}=.277 \mathrm{~d}, \mathrm{p}=.782)$ but did report reduced nervousness $(\mathrm{z}=2.106, \mathrm{p}=0.035)$, increased confidence $(\mathrm{z}=4.491, \mathrm{p}<0.001)$ and greater ability to show empathy $(z=2.034, p=0.042)$ at Week 7 . Tests for the effects of age showed that the under 30 group reported a significant reduction in nervousness $(\mathrm{z}=2.350, \mathrm{p}=.019)$ while the $30+$ age group did not $(\mathrm{z}=.179, \mathrm{p}=.858)$. As all the males were contained within the Service User/Drama Group, analysis examining the effect of gender was only conducted within this group. Females showed a significant decrease in reported nervousness $(\mathrm{z}=2.475, \mathrm{p}=.013)$ and increased 
confidence $(\mathrm{z}=3.997, \mathrm{p}<.000)$ while males reported a significant increase in confidence $(\mathrm{z}=$ 2.123, $\mathrm{p}=.034)$ and ability to show empathy $(\mathrm{z}=2.460, \mathrm{p}=.014)$. Figure 1 highlights that, although the Drama/Service User Group tended to rate the role play experience more negatively at Week 4 compared to those in the Service User/Drama Group, by Week 7, the ratings between the two groups were equivalent, with the exception of nervousness, which was reduced for those with a drama student role play at Week 7.

The survey also included open response questions asking about the strengths and limitations of conducting the role play with a service user or drama student at Week 4 and Week 7. Table 3 summarises these responses, indicating a high degree of symmetry between student perceptions of role plays with drama students and services users, regardless of the timing. Drama students tended to engender less anxiety amongst students and provided a safer environment for them to practice and develop their skills. At the same time, they were perceived as less realistic and somewhat less likely to engender genuine empathy. By contrast,

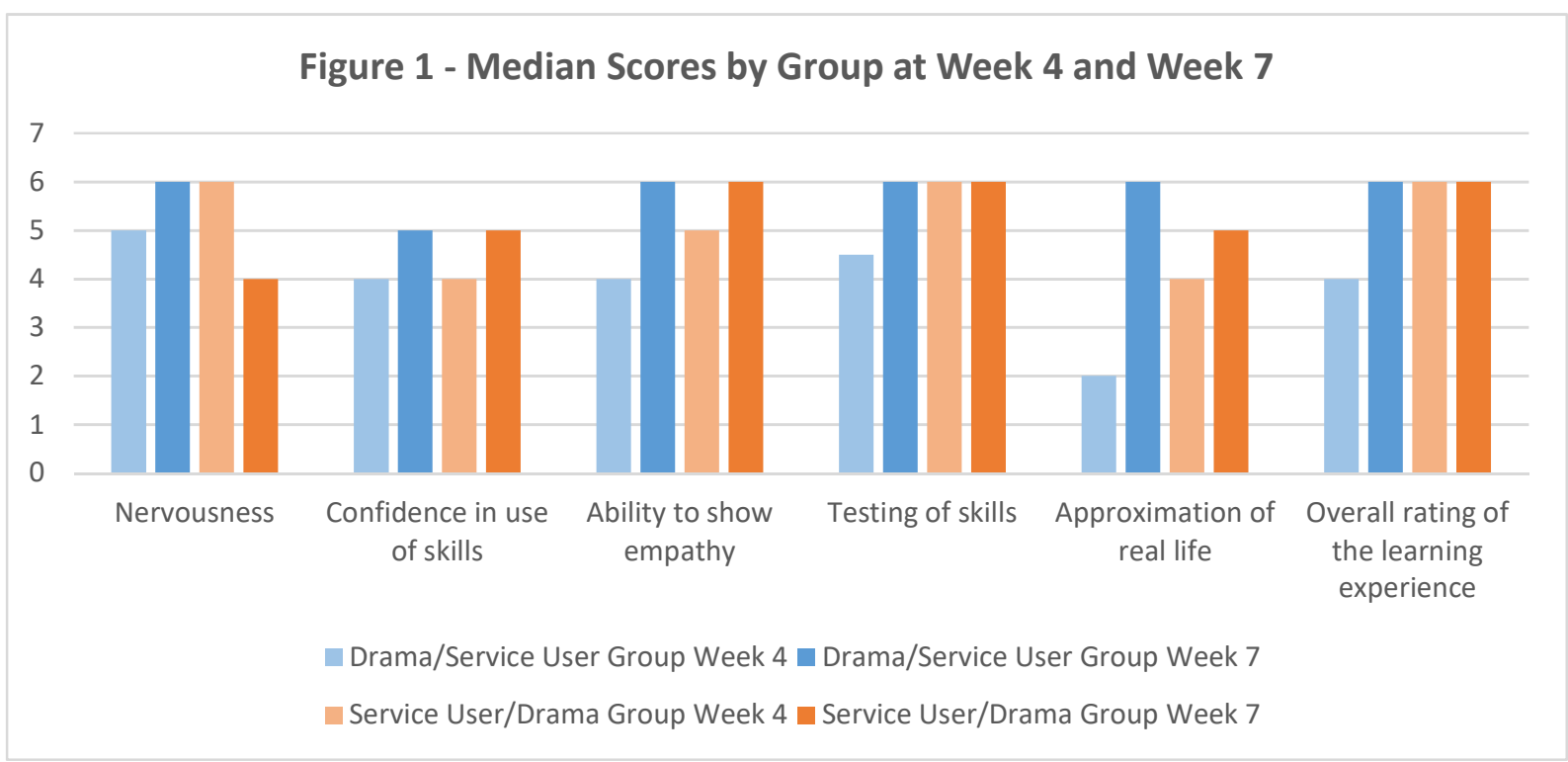

service user role plays tended to increase student pressure and levels of anxiety but were perceived as more realistic and as providing a valuable opportunity for the students to practice their skills and receive feedback from someone with real world experience. It is worth noting that a number of students commented on the abilities of the drama student, indicating that they 
did not feel that their engagement in Week 7, following a service user in Week 4, detracted from the authenticity of the scenario due to the skilled performance given by the student.

Table 3 - Strengths and limitations of conducting the role play with a service user or drama student at Week 4 and Week 7

\begin{tabular}{|c|c|c|c|}
\hline Strengths & Limitations & Strengths & Limitations \\
\hline \multicolumn{2}{|l|}{ Drama Student at Week 4} & \multicolumn{2}{|l|}{ Service User at Week 7} \\
\hline $\begin{array}{l}\text { - More at ease/less } \\
\text { nervous } \\
\text { - Less pressure/less } \\
\text { intimidating } \\
\text { - Not as worried about } \\
\text { mistakes/upsetting a } \\
\text { real life service user } \\
\text { - Practice and apply } \\
\text { skills/identify areas } \\
\text { for improvement } \\
\text { - Ease into role } \\
\text { play/assessment }\end{array}$ & $\begin{array}{l}\text { - Artificial/unrealistic/st } \\
\text { aged } \\
\text { - Harder to show } \\
\text { empathy } \\
\text { - Didn't take as seriously } \\
\text { - Less } \\
\text { information/context }\end{array}$ & 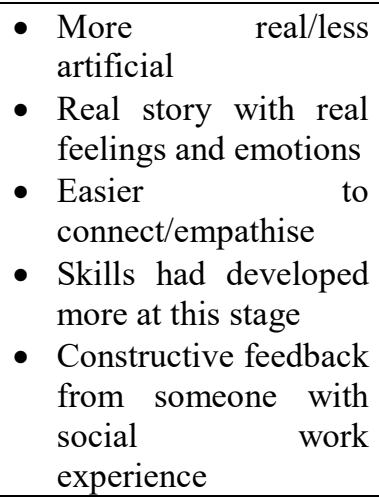 & 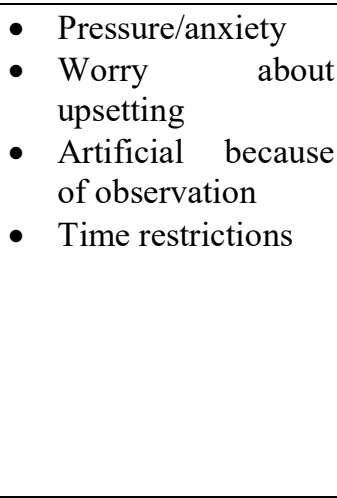 \\
\hline \multicolumn{2}{|l|}{ Service User at Week 4} & \multicolumn{2}{|l|}{ Drama Student at Week 7} \\
\hline 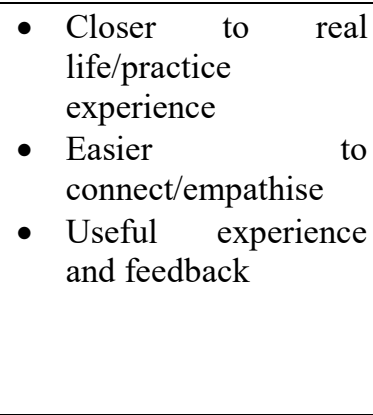 & $\begin{array}{l}\text { - Nerves/pressure/anxiet } \\
\text { y about } \\
\text { - Worry upsetting/offending } \\
\text { - Daunting because of } \\
\text { peer observation }\end{array}$ & 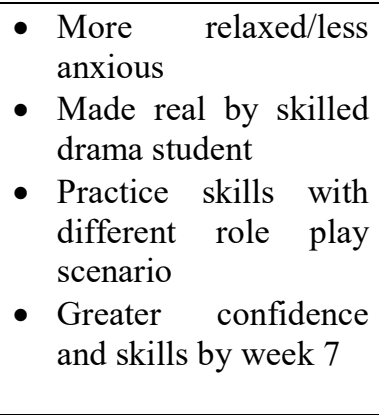 & 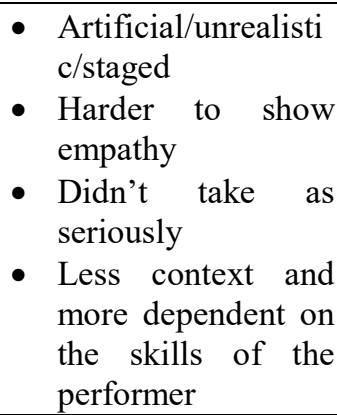 \\
\hline
\end{tabular}

\section{Summary}

Students in both groups reported reduced nervousness, increased confidence in the use of their skills, ability to show empathy, greater approximation of the role play to real life practice and higher overall rating of the learning experience between Week 4 and Week 7. Unsurprisingly, role plays with service users were considered to approximate real life more than those with drama students, regardless of timing, a finding which was supported by qualitative comments. Nonetheless, students also reported that they found role plays with drama students less 
pressurized and intimidating and that they allowed them to practice their skills without fear of upsetting a 'real-life' service user. Given that younger students reported higher levels of nervousness, the opportunity to practice skills with drama students at an earlier stage may be a particular benefit to this group. Importantly, the quantitative analysis found that, with the exception of nervousness, the ratings of both groups were equivalent at Week 7 , suggesting that the drama student/service user model is a feasible and practical alternative to the use of service users in all role plays. It is also important to recognise that there were three cohorts of students in this research with differing degrees of experience, reduced nervousness may therefore also be attributable to having had more life experience particularly for those students in the RGR and PTR routes.

\section{Service User Focus Group}

Due to timing issues, only two service users attended a focus group to discuss this collaboration. Service users did not observe the input from the drama students, so their comments relate to their own engagement with students in the role play scenarios which occurred in week 11 of the module. The following themes were identified:

In terms of nervousness, the service users acknowledged that students were very nervous when conducting these role-play interviews attributing this largely to the fact that the interviews were being assessed:

I thought they (the students) were very nervous, I think because they are trying to meet the criteria, ...they are always very nervous.

Service users, however, offered strategies to try to redress student nervousness.

Ijust asked them to take a big breath to help them relax.

In terms of confidence, to a large extent, the service users perceived that the students felt confident during the interview: 
I think this year they seemed to be very confident; whether that is confidence in themselves or in the role play...definitely I thought the ones I dealt with were very confident.

In terms of how real the role plays felt, both services users identified that many students managed the role-play as though it was a real-life social work intervention.

I thought because my situation was real, I was a real person; they were coming in to help me because it's real for them and for me.

However, services users identified that some students appeared too prepared and were perceived as performing a role: they asked specific questions because they wanted specific answers but when I threw a clanger in, they weren't prepared for that.

Students who seemed to be 'over prepared' were seen to differ from those students who more genuinely engaged with the service users, and who were more able to display genuine empathy: When you do get that empathy and connection, that works, that's why I said to a couple of them I wish you had been around as my social worker, they bring a freshness. Some are very mature in their approach. You notice a phrase where they have really got what you're talking about. A final key theme identified related to feedback, service users emphasised the important role they played in giving feedback to students suggesting that such feedback was of significant value in the student's professional development:

They wanted to hear my input and it was interesting how they find the value of that and how they use that real experience.

\section{Focus Group with Drama Students}

Eight out of the cohort of 16 Drama students provided feedback in this focus group. The following themes were identified. In terms of nervousness there was general consensus that the social work students were nervous:

Yes, there were even a few that panicked and froze on the spot; their nerves took over a bit. 
In terms of confidence, the response was mixed insofar as there was not always a corresponding relationship between confidence at the start and subsequent performance during the simulated interview. The age of the social work student seemed to have a more positive influence on their performance:

There was one girl and she was very confident and then it kind of went the opposite way, the nerves overtook her throughout the thing...the older the age of the student, the more confident they were.

In terms of empathy, the students' preoccupation with completing a checklist rather than engaging more empathetically with the drama students presented as an obstacle:

So I did it 14 times and not one of them gave me a chance to say hello or not one of them asked 'how are you today' or 'how are you' or even an empathetic introduction.

Thinking about how well the role-plays tested the skills of the social work students, the main theme seemed to be the size of the groups and the relative impact on the fidelity of the simulation:

I think as an examination of their personal skills it wasn't really that effective that it was in such big groups, because so you did it twice with two groups of seven and whoever was the seventh person to go at that point they knew exactly what to ask me.

In terms of how close the role-play with social work students felt to real life, the consensus was that some of the simulations seemed close to real life, but the comparison between the two different learning styles in Drama and Social Work became the predominant theme:

A lot of people were commenting on how real they felt it was and there was a lot of emotion with the students in my room, they felt really emotional towards the things I was saying. I think if we prepare well then it will be authentic and real to a certain extent... 
Reflecting on the strengths and limitations of working with the social work students, the main issues pertained to the social work students' over-reliance on notes and their performance being somewhat mechanical:

Some of them were very strong and they knew what they were saying and some of them they would forget what their line was which broke it off for me and I got out of the role.

\section{Focus Group with Tutors}

Five members of the tutoring team participated in this focus group. The following themes emerged. In terms of nervousness there was consensus among participants that, in general, the social work students were more nervous with the service user educators although this was framed in positive terms:

I think they were more nervous with the service users. But, that's not necessarily a bad thing because they were also more mindful of being respectful, so actually, while they were more nervous, it was possibly a good nervousness as it came out of not wanting to cause anyone any harm (Tutor 1). Tutor 2 also suggested that the student social workers "probably did take it more seriously when it came to the service users."

In terms of confidence, there was consensus that all of the students were more confident in the later weeks regardless of which part of the study they were in, but tutors had not worked across groups and so could not compare. There was also some discussion about the importance of preparing both drama students and service user educators as there were some concerns identified about standardisation between and within the roles.

In terms of how real the role-plays felt, Tutor 3 suggested that, for his group which were Drama/Service user "They just didn't feel it was real and then they had a service user and they felt it was a much more real experience." Although Tutor 1 reported that, "With the actor it was really emotional. It shocked me. I suppose it depends on the acting ability and the scenario being played out. Our service user cried through most of the sessions in week eleven. It was 
very raw, some of the stuff she was talking about. They coped with it very well, checking on her welfare."

Tutor 4 also highlighted some of the potential strengths of the drama students: "the drama student could think beyond the story, as the service users were curtailed by their actual reality". This was reinforced by Tutor 5 who stated: "One of the benefits of the drama students was that they gave more critical feedback.....as where the service users were inclined to be more helpful."

Tutor 5 also summarised some of the key themes: "I suppose strengths of the drama students were that I found they were very well prepared.... The weakness: it's not real, it's artificial. The strength of the service users was that the students do react to them different. They approach it in a different way, they take it more seriously."

In terms of what the ideal approach might be Tutor 2 said: "I think there is a place for both, but I think drama students first. And service users for the final."

\section{Summary}

The findings from the focus groups with service users, drama students and tutors all concur that the students were nervous in the role plays with both the service users and drama students. Viewed positively, this could indicate the seriousness with which the students are approaching their preparation for real practice. The overly mechanistic and rigid nature of practice evidenced by some students in the role plays may be an expression of students seeking structure and a sense of security in their performance. This can be developed with further practice, review and self-evaluation. It was evident that role plays which were perceived as real and authentic can be achieved by both service users and drama students. However, importantly, students tended to take the role plays more seriously when service users were involved. Direct and critical feedback from drama students was recognised as positive aspect of their involvement. 


\section{Discussion and Implications}

A question central to the debate on how best to prepare social work students for the realities of social work practice is what works as reality-based preparation? The ethical consequences of involving people with 'real life' experiences in the education of social work students, and the extent to which simulated based knowledge can deliver in terms of adequately addressing social work competence, are important factors in the debate. These are the challenges and questions of epistemology with which this pedagogic research project immersed.

So, based on our findings, what we can conclude is that there is a place for both service user and simulated knowledge in social work education. Consistent with what is already established in the literature (Cooper and Spencer Dawe, 2006; Skilton, 2011; McLaughlin et al, 2018; Robinson and Webber, 2013), service users with lived experience of being on the 'receiving end' of social work services, have brought authenticity, reality and improved confidence to the students particularly in the evidencing of empathy as a key skill. In addition, drama students have helped the social work students feel less nervous, creating a safe learning space, providing direct and critical feedback and also helped with their developing confidence. The latter finding also concurs with the important positioning of simulation in social work education (see, for example, Bogo and Rawlings, 2016). We do not think, therefore, it is a case of one or the other type of approach but more of a hybrid option involving both. Working with drama students at the beginning of social work skills practice sessions will help the social work students overcome issues around nervousness and confidence, particularly important for younger students in a safe learning environment. This is already recognised in the social work education literature as being important (Moss et al, 2007). Working then at a later point with service users will help the students evidence the confidence they need for entering a more reality based helping encounter. This type of hybrid approach, combining simulation and service user experience-based knowledge, will, therefore, represent an important pedagogic innovation 
where differing knowledges (Rose, 2009) are espoused from different standpoints (Harding, 1991). Whilst our research points to a model for adopting drama students and service users, there are also inherent challenges. To address the insidious impact of 'othering' (Beresford, 2013), service users and drama students should work together closely in key stages of the process. For example, in giving feedback, this may help deal with the criticism that service users are overly positive in their feedback and find difficulty in addressing poor performance (Thomas, 2002; Crisp et al, 2006). Drama students, working closely with the service users, can also further hone their acting skills by getting even closer to representing reality and authenticity in their role play performances. All the while however, a further challenge is the need to provide meaningful preparation and support to service users given that it can be difficult to both attract and sustain service user involvement in social work education (Levin, 2004; Duffy, 2006).

This hybrid approach can also help instil in social work students a sense that service users can work in real partnership in a joint learning endeavour. This can, therefore, convey important messages about trust, collaborative relationships and social justice rooted relationships which ultimately are at the core of and central to social work practice and which can transfer to the practice world (Levin, 2004; Baldwin and Sadd, 2006; Levy et al, 2018) particularly in terms of "modelling good practice for the future" (Driessens et al, 2016:741). Therefore, experiencing service users in such an important and elevated role can also help social work students continue to see service users through this positive lens as they endeavour to meaningfully achieve partnership relationships.

\section{Conclusion}

This research has looked, for the first time, at the comparative contribution of drama students and service users to the skills development of social work students in a university in Northern 
Ireland. Our findings have evidenced that there is an important place for working collaboratively with drama students and service users in helping develop more fidelity-based field practice preparations for social work students. A strength of this pedagogic research is the systematic approach to comparing the contributions from both service users and drama students at an important stage of skills assessment with social work students. A weakness of this research is the relatively small research populations involved with just one university which potentially limits the generalisability of our findings. An additional weakness is the ethical implications of potentially weakening/lessening the involvement of service users by our advocating of this joint/hybrid approach, involving drama students and service users, when there is considerable and important evidence to show that service user involvement, as a distinct form of experiential based pedagogy in social work education, has achieved so much right across the United Kingdom since being first introduced in 2002. Service user involvement has, therefore, rightfully gained its place at the centre of social work education. What, however, reassured us as a research team, was the encouragement and support we gained from the service user educators involved who were keen to advance the evidence base in the field. They wanted to know how their involvement compared to that of drama students and did not from the outset, therefore, see this research in terms of negatively impacting on their continuing or future involvement. On the contrary, they wanted to be a part of furthering the distinct epistemology of service user involvement and therefore fully supported the research.

We argue that this approach to social work education can help further develop achievements to date in both the U.K. and internationally in regard to both service user involvement in social work education and in simulation approaches to preparing students for practice. Future approaches can, therefore, embody drama and service user informed teaching and preparation which can, not only apply to social work, but also to other health and professional education contexts such as Nursing and Medicine. This joint approach could also contribute to ongoing 
innovations in Virtual Reality and in the growing focus on development of simulation centres to address the multi-disciplinary learning needs of other professions, as mentioned already. Ultimately, service users of social work require social workers to be sensitised to their needs and effective in their professional responses. We, therefore, argue that adopting this hybrid model in social work education, recognising the differing knowledges from simulation and lived experience, can make an important combined contribution to the competence development of social work students to enable them to enter field practice with confidence. 


\section{REFERENCES}

Ackroyd, J. (2000) 'Applied Theatre: Problems and Possibilities', Applied Theatre Journal, 1

Baldwin, M., \& Sadd, J. (2006). Allies with attitude! Service users, academics and social service agency staff learning how to share power in running social work education courses. Social Work Education: The International Journal, 25, 348-359.

Banks, S. (2006) Ethics and Values in Social Work, 3rd edn. Basingstoke: Palgrave Macmillan. Beresford, P. (2000) 'Service Users' Knowledges and Social Work Theory: Conflict or Collaboration?' British Journal of Social Work. Vol 30(4): 489-503.

Beresford, P. (2005) “Service user”: regressive or liberatory terminology? Disability \& Society, 20 (4): 469-77.

Beresford, P. (2013) From 'other' to involved: User involvement in research: an emerging paradigm, Nordic Social Work Research. Vol. 3 (2):139- 148

Bogo, M. \& Rawlings, M. (2016). Using simulation in teaching and assessing social work competence. In Taylor, I. Bogo, M., Lefevre, M. \& Teater, B. (Eds.) International Handbook of Social Work Education. pp. 265-274. Abingdon, England: Routledge.

Carpenter, J. (2011). Evaluating social work education: A review of outcomes, measures, research designs and practicalities. Social Work Education, 30(02), 122-140.

Cooper, H. \& Spencer-Dawe, E. (2006) 'Involving service users in interprofessional education narrowing the gap between theory and practice', Journal of Interprofessional Care, vol. 20, no. 6, pp. 603-617.

Cotterell, P and Morris, C (2012) 'The Capacity, Impact and Challenge of Service Users' Experiential Knowledge' in M. Barnes, \& P. Cotterell (eds.), Critical perspectives on user involvement. Bristol: The Policy Press, pp. 57-70

Crisp, B. R., Lister, P. G. \& Dutton, K. (2006) 'Not just social work academics: the involvement of others in the assessment of social work students', Social Work Education, Vol. 25(7): pp. $723-734$.

DHSSPS (2003) Northern Ireland Framework Specification for the Degree in Social Work. Belfast: Department of Health, Social Services and Public Safety.

DOH (2002) Requirements for Social Work training. London: Department of Health.

Dill, K., Montgomery, L., Davidson, G., Duffy, J (2016) 'Service User Involvement in Social Work Education: The Road Less Travelled'. Field Education Journal. Vol 6(2) pp. 1-11.

Douglas, H. \& McColgan, M. (1999) 'Preparation for Contact: an aid to effective intervention', The Journal of Practice Development, 7(2):53-64. 
Driessens, K., McLaughlin, H. \& Van Doorn, L (2016) The Meaningful Involvement of Service Users in Social Work Education: Examples from Belgium and The Netherlands, Social Work Education, 35:7, 739-751, DOI: 10.1080/02615479.2016.1162289

Duffy, J. (2006) Participating and Learning - Citizen Involvement in Social Work Education in a Northern Ireland Context. London. Social Care Institute for Excellence (SCIE). www.scie.org.uk/publications/misc/citizeninvolvement.pdf

Duffy, J (2012) Service user involvement in teaching about conflict - an exploration of the issues. International Social Work (Special Edition on Social Work and Armed Conflict).Vol 55(5) pp. $720-739$.

Duffy, J., Das, C and Davidson, G (2012) 'Service User and Carer Involvement in Role-plays to Assess Readiness for Practice', Social Work Education, doi:10.10 $80 / 02615479.2011 .639066$

Duffy, J (2015) Illuminating pedagogy through experiential knowledge. Heslington. York. Higher Education Academy.

Edwards, C. (2003). The involvement of service users in the assessment of diploma in social work students on practice placements. Social Work Education, 22, 341-349.

El Enany, N., Currie, G. and Lockett, A. (2013) A Paradox in Healthcare service development: professionalization of service users. Social Science and Medicine, 80 (1): 24-30.

Eraut, M. (1996) 'Developing Professional Knowledge and Competence'. Routledge. London Fook, J. (1999) 'Reflexivity as Method'. Annual Review of Health Social Sciences. Vol 9:1120 .

Fisher, M (2015) How to Write About Theatre. London: Bloomsbury Methuen.

Freire, P. (1972) 'Pedagogy of the oppressed.' New York: Herder and Herder.

Harding, S. (1991) Whose science? Whose knowledge? Thinking from Women's Lives. New York: Cornell University Press.

Hernandez, L.,Robson, P. and Sampson, A (2010) Towards Integrated Participation: Involving Seldom Heard Users of Social Care Services, British Journal of Social Work 40, 714-736 doi:10.1093/bjsw/ben118

Hugman, R. (2005) New approaches in ethics for the caring profession. Basingstoke: Palgrave Macmillan.

Levin, E. (2004) Involving Service Users and Carers in Social Work Education, SCIE Guide 4, London, Social Care Institute for Excellence. 
Levy, S., Aiton, R., Doig, J., Dow, J.P.L., Brown, S., Hunter, L and McNeil, R (2018) 'Outcomes focused user involvement in social work education: applying knowledge to practice' in H. McLaughlin., J. Duffy., B. McKeever \& J. Sadd (2018). Service User Involvement in Social Work Education. London/New York. Routledge.

McLaughlin, H. (2009). What's in a Name: 'Client', 'Patient', 'Customer', 'Consumer', 'Expert by Experience', 'Service User'--What's Next? British Journal of Social Work. 39(6), pp.11011117.

McLaughlin, H. (2010). Keeping Service User Involvement in Research Honest. British Journal of Social Work. 40(5): pp.1591-1608.

McLaughlin, H., Duffy, J., McKeever, B., Sadd, J (2018). Service User Involvement in Social Work Education. London/New York. Routledge.

Moss, B. R., Dunkerly, M., Price, B., Sullivan, W., Reynolds, M. \& Yates, B. (2007) 'Skills laboratories and the new social work degree: one small step towards best practice? Service users' and carers' perspectives', Journal of Social Work Education, Vol. 26(7) pp. 708-722. Nicholson, H. (2014) ‘Applied Drama: The Gift of Theatre.’ Basingstoke: Palgrave Macmillan. Popay, J. and Williams, G (1996) Public health research and lay knowledge. Social Science and Medicine, 42 (5) 759-68.

Prior, L. (2003) Belief, knowledge and expertise: the emergence of the lay expert in medical sociology. Sociology of Health \& Illness, 25, (1) 41-57.

Reupert, A (2007) Social Worker's Use of Self, Journal of Clinical Social Work. 35:107-116 DOI 10.1007/s10615-006-0062-4.

Reupert, A (2009) Students' Use of Self: Teaching Implications, Social Work Education, 28:7, 765-777, DOI: 10.1080/02615470802512689.

Rimmer, A. (1997) Power and dignity: women, poverty and credit unions. Gender Development, 5 (3) 26-34.

Rose, D. (2009) 'Survivor-produced knowledge' In: Sweeney A., Beresford P., Faulkner A., Nettle M. and Rose D. (eds.) This is Survivor Research. Ross-on-Wye. PCCS Books Ltd, pp. $38-44$.

Robinson, K. and Webber, M. (2013) 'Models and effectiveness of service user and carer involvement in social work education: A literature review', British Journal of Social Work, 43(5), pp. 925-44.

Shennan, G. (1998) 'Are we asking the experts? Practice teachers' use of client views in assessing student competence', Social Work Education, Vol. 17, pp. 407-417. 
Shulman, L. (1999) The Skills of Helping Individuals, Families, Groups and Communities (fourth edition), Illinois. F.E. Peacock Publishers.

Skilton, C. J. (2011) 'Involving experts by experience in assessing students' readiness to practise: the value of experiential learning in student reflection and preparation for practice', Social Work Education, Vol. 30, no. 3, pp. 299-311.

Stanislavski, K (2016) An Actor's Work, Jean Benedetti (trans). London: Routledge.

Taylor, P (2003) Applied Theatre: Creating Transformative Encounters in the Community. Portsmouth, NH: Heinemann.

Thomas, R. (2002) 'Creative assessment: involving service users in student assessment in social work', Journal of Practice Teaching, Vol. 4(10: pp. 27-43.

Thompson, J (2003) ‘Applied Theatre: Bewilderment and Beyond.' Oxford: Peter Lang.

Trevithick, P. (2008) 'Revisiting the Knowledge Base of Social Work: A Framework for Practice. British Journal of Social Work. Vol 38: 1212-1237.

Ward, L and Gahagan, B. (2012) Involving older people in research: empowering engagement? In: Barnes M., and Cotterell, P. (eds.) Critical perspectives on user involvement. Bristol: The Policy Press, pp. 181-9.

Wilson, G and Campbell, A. (2013) 'Developing Social Work Education: Academic Perspectives' British Journal of Social Work. Vol 43, pp.1005-1023. 